\title{
Mineral Resources of the Black Rock Wilderness Study Area, Graham County, Arizona
}
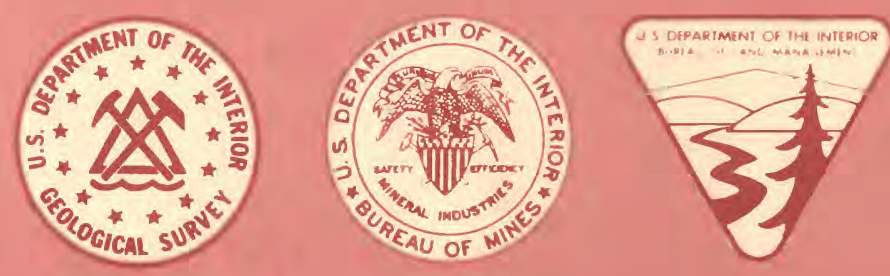

\section{U.S. GEOLOGICAL SURVEY BULLETIN 1703-C}

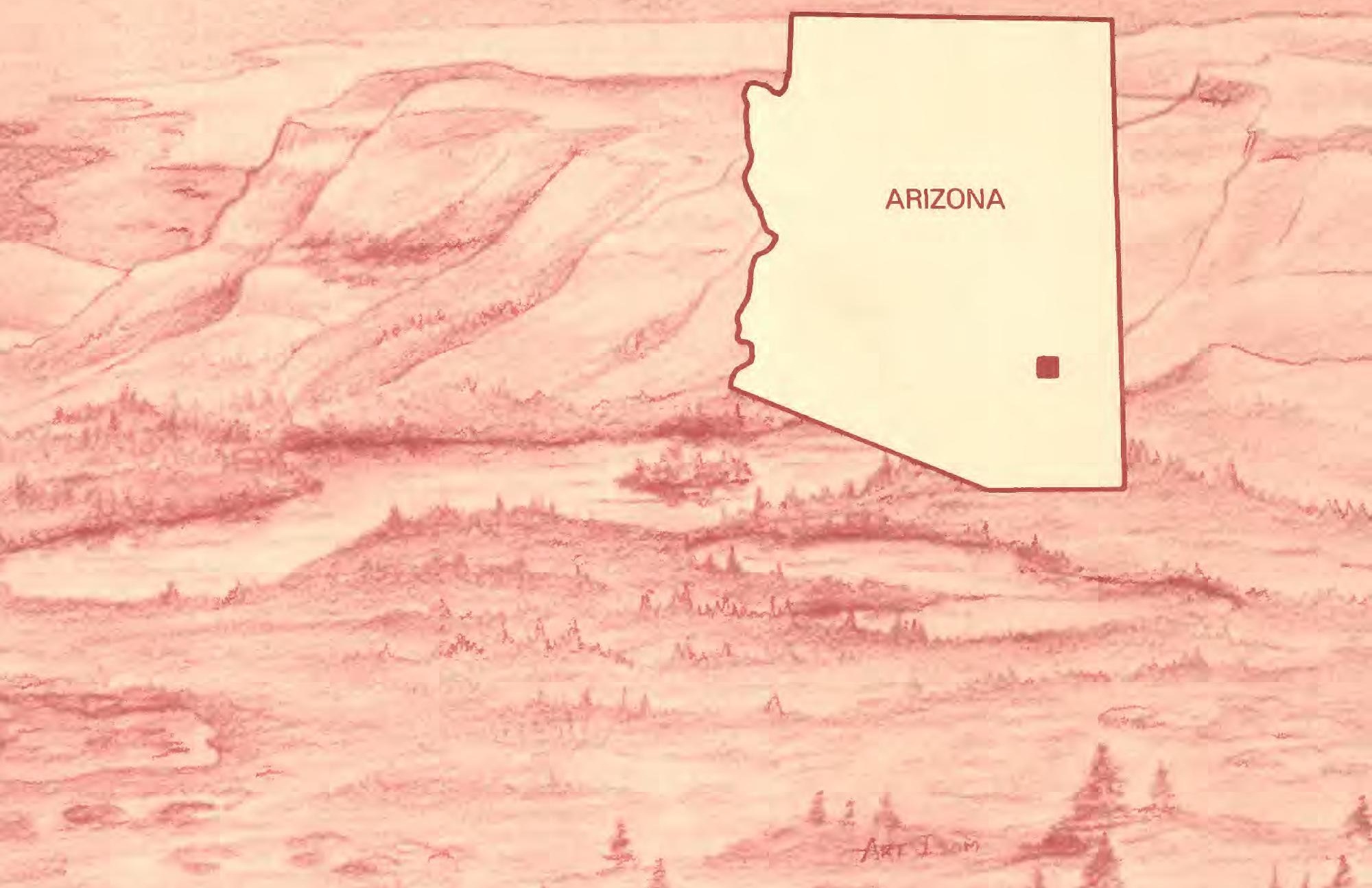




\section{DEFINITION OF LEVELS OF MINERAL RESOURCE POTENTIAL AND CERTAINTY OF ASSESSMENT}

\section{Definitions of Mineral Resource Potential}

LOW mineral resource potential is assigned to areas where geologic, geochemical, and geophysical characteristics define a geologic environment in which the existence of resources is unlikely. This broad category embraces areas with dispersed but insignificantly mineralized rock as well as areas with few or no indications of having been mineralized.

MODERATE mineral resource potential is assigned to areas where geologic, geochemical, and geophysical characteristics indicate a geologic environment favorable for resource occurrence, where interpretations of data indicate a reasonable likelihood of resource accumulation, and (or) where an application of mineral-deposit models indicates favorable ground for the specified type(s) of deposits.

HIGH mineral resource potential is assigned to areas where geologic, geochemical, and geophysical characteristics indicate a geologic environment favorable for resource occurrence, where interpretations of data indicate a high degree of likelihood for resource accumulation, where data support mineral-deposit models indicating presence of resources, and where evidence indicates that mineral concentration has taken place. Assignment of high resource potential to an area requires some positive knowledge that mineral-forming processes have been active in at least part of the area.

UNKNOWN mineral resource potential is assigned to areas where information is inadequate to assign low, moderate, or high levels of resource potential

NO mineral resource potential is a category reserved for a specific type of resource in a well-defined area.

\section{Levels of Certainty}

\begin{tabular}{|c|c|c|c|}
\hline \multirow{4}{*}{$\begin{array}{l}\text { UNKNOWN } \\
\text { POTENTIAL }\end{array}$} & $\begin{array}{l}\text { H/B } \\
\text { HIGH POTENTIAL }\end{array}$ & $\begin{array}{l}\text { H/C } \\
\text { HIGH POTENTIAL }\end{array}$ & $\begin{array}{l}\text { H/D } \\
\text { HIGH POTENTIAL }\end{array}$ \\
\hline & $\begin{array}{l}\text { M/B } \\
\text { MODERATE POTENTIAL }\end{array}$ & $\begin{array}{l}\text { M/C } \\
\text { MODERATE POTENTIAL }\end{array}$ & $\begin{array}{l}\text { M/D } \\
\text { MODERATE POTENTIAL }\end{array}$ \\
\hline & L/B & $\mathrm{L} / \mathrm{C}$ & $\begin{array}{l}\text { L/D } \\
\text { LOW POTENTIAL }\end{array}$ \\
\hline & POTENTIAL & POTENTIAL & $\begin{array}{l}\text { N/D } \\
\text { NO POTENTIAL }\end{array}$ \\
\hline A & B & C & D \\
\hline
\end{tabular}

A. Available information is not adequate for determination of the level of mineral resource potential.

B. Available information suggests the level of mineral resource potential.

C. Available information gives a good indication of the level of mineral resource potential.

D. Available information clearly defines the level of mineral resource potential.

\section{Abstracted with minor modifications from:}

Taylor, R. B., and Steven, T. A., 1983, Definition of mineral resource potential: Economic Geology, v. 78 , no. 6, p. $1268-1270$.

Taylor, R. B., Stoneman, R. J., and Marsh, S. P., 1984, An assessment of the mineral resource potential of the San Isabel National Forest, south-central Colorado: U.S. Geological Survey Bulletin 1638, p $40-42$.

Goudarzi, G. H., compiler, 1984, Guide to preparation of mineral survey reports on public lands: U.S Geological Survey Open-File Report 84-0787, p. 7, 8. 
Chapter C

\section{Mineral Resources of the Black Rock Wilderness Study Area, Graham County, Arizona}

By FRANK S. SIMONS, PAUL K. THEOBALD, RONALD R. TIDBALL, JAMES A. ERDMAN, THELMA F. HARMS, and ANDREW GRISCOM U.S. Geological Survey

GEORGE S. RYAN U.S. Bureau of Mines 


\title{
DEPARTMENT OF THE INTERIOR DONALD PAUL HODEL, Secretary
}

\author{
U.S. GEOLOGICAL SURVEY \\ Dallas L. Peck, Director
}

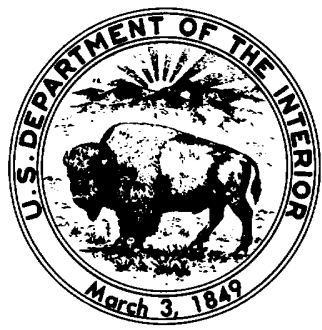

For sale by the

Books and Open-File Reports Section

U.S. Geological Survey

Federal Center

Box 25425

Denver, CO 80225

Library of Congress Cataloging in Publication Data

Mineral resources of the Black Rock Wilderness Study Area, Graham County, Arizona

(Mineral resources of wilderness study areas-Southeastern Arizona; ch.

C) (U.S. Geological Survey bulletin ; 1703-C)

Bibliography: $p$.

Supt. of Docs. No.: | 19.3:1703-C

1. Mines and mineral resources-Arizona-Black Rock Wilderness. 2.

Geology-Arizona-Black Rock Wilderness. 3. Black Rock Wilderness (Ariz.)

I. Simons, Frank S. (Frank Stanton), 1917-

U.S. Geological Survey bulletin ; 1703-C.

QE75.B9

no. $1703-C$

$557.3 \mathrm{~s}$

II. Series. III. Series:

[TN24.A6]

[553'.09791'54]

$86-600281$ 


\section{STUDIES RELATED TO WILDERNESS}

\section{Bureau of Land Management Wilderness Study Areas}

The Federal Land Policy and Management Act (Public Law 94-579, October 21, 1976) requires the U.S. Geological Survey and the U.S. Bureau of Mines to conduct mineral surveys on certain areas to determine the mineral values, if any, that may be present. Results must be made available to the public and be submitted to the President and the Congress. This report presents the results of a mineral survey of part of the Black Rock (AZ-040-008) Wilderness Study Area, Graham County, Arizona. 


\section{RESOURCE/RESERVE CLASSIFICATION}

\begin{tabular}{|c|c|c|c|c|c|}
\hline \multirow[b]{3}{*}{ ' } & \multicolumn{3}{|c|}{ IDENTIFIED RESOURCES } & \multirow{2}{*}{\multicolumn{2}{|c|}{$\frac{\text { UNDISCOVERED RESOURCES }}{\text { Probability Range }}$}} \\
\hline & \multicolumn{2}{|c|}{ Demonstrated } & \multirow{2}{*}{ Inferred } & & \\
\hline & Measured & Indicated & & Hypothetical & Speculative \\
\hline ECONOMIC & & ves & Inferred Reserves & & \\
\hline $\begin{array}{l}\text { MARGINALLY } \\
\text { ECONOMIC }\end{array}$ & Margin & eserves & $\begin{array}{l}\text { Inferred } \\
\text { Marginal Reserves }\end{array}$ & & \\
\hline $\begin{array}{c}\text { SUB - } \\
\text { ECONOMIC }\end{array}$ & $\begin{array}{r}\text { Dem } \\
\text { Subeconor }\end{array}$ & $\begin{array}{l}\text { Strated } \\
\text { Resources }\end{array}$ & $\begin{array}{c}\text { Inferred } \\
\text { Subeconomic } \\
\text { Resources }\end{array}$ & & \\
\hline
\end{tabular}

Major elements of mineral resource classification, excluding reserve base and inferred reserve base. Modified from U. S. Bureau of Mines and U. S. Geological Survey, 1980, Principles of a resource/reserve classification for minerals: U. S. Geological Survey Circular 831, p. 5. 


\title{
CONTENTS
}

\author{
Summary 1 \\ Introduction $\mathbf{3}$ \\ Investigations by the U.S. Bureau of Mines 4 \\ Investigations by the U.S. Geological Survey 4 \\ Appraisal of identified resources 4 \\ Mining and mineral-exploration activity 4 \\ Mines, prospects, claims, and leases 4 \\ Assessment of potential for undiscovered resources 5 \\ Geology 5 \\ Geophysics 7 \\ Geochemistry 7 \\ Mineral and energy resources 8 \\ References cited 9
}

\section{PLATE}

1. Mineral resource potential, geologic, and geochemical sample locality map of the Black Rock Wilderness Study Area In pocket

\section{FIGURES}

1. Mineral resource potential map of the Black Rock Wilderness Study Area 2

2. Index map showing the location of the Black Rock Wilderness Study Area 3

\section{TABLES}

1. Anomalous elements in samples of stream sediments and mesquite leaves 3

2. Analytical data for U.S. Bureau of Mines samples 5

3. Analytical data for U.S. Geological Survey samples from prospects 6

4. Analytical data for samples of other rocks 7 
1 


\title{
Mineral Resources of the Black Rock Wilderness Study Area, Graham County, Arizona
}

\author{
By Frank S. Simons, Paul K. Theobald, Ronald R. Tidball, James A. Erdman, \\ Thelma F. Harms, and Andrew Griscom \\ U.S. Geological Survey and \\ George S. Ryan \\ U.S. Bureau of Mines
}

\section{SUMMARY}

The Black Rock (AZ-040-008) Wilderness Study Area is in the eastern foothills of the Santa Teresa Mountains in western Graham County, southeastern Arizona (fig. 1). It has an area of 8,492 acres, of which mineral surveys were requested on 6,590 acres (about $10.3 \mathrm{mi}^{2}$ or square miles). Throughout this report "wilderness study area" and "study area" refer only to the acreage studied.

The predominant geographic feature in the wilderness study area is Black Rock, an oval plug of rhyolite nearly a mile long that rises as much as $1,000 \mathrm{ft}$ (feet) above its base and in the upper part is encircled by cliffs several hundred feet high. South and southeast of Black Rock, varicolored volcanic rocks, mostly red, have been deeply dissected into narrow steep-walled canyons surmounted by rugged crags and spires. Jackson Mountain, in the southeastern corner of the area, is the highest point $(5,890 \mathrm{ft})$.

Rocks in the area include metamorphic and igneous rocks of Proterozoic (2,500 to about 570 m.y. or million years; see geologic time chart on the last page of this report) age, Santa Teresa Granite of Tertiary (63-1.7 m.y.) age, volcanic rocks of various compositions of Tertiary age, and fanglomerate of Tertiary and Quaternary (younger than $1.7 \mathrm{~m} . \mathrm{y}$.) age. Contacts of volcanic rocks with metamorphic rocks and granite are along faults.

A mineral survey of the area was made in 1983 and 1984. Some mineral prospecting probably was done as early as 1880 but most was done after 1896 , particularly during 1898-99 as part of a fraudulent mining venture named Spenazuma (Ridgway, 1957). A dozen or so prospects are in or near the study area; all of them within the study area are in volcanic rocks.
No mineral reserves or identified resources are within the study area (fig. 1). Mineralized areas within and near the study area are on the flanks of small magnetic highs and are also on the northern flank of a broad magnetic high, but the apparent association of mineralization with these magnetic anomalies is not clearly understood. Area 1 in the western part of the study area has a moderate mineral resource potential for thorium, rare-earth elements, and tin; area 2 in the central part of the study area has a moderate potential for thorium and beryllium; area 3 in the central part has a moderate potential for copper, lead, molybdenum, cobalt, tin, and vanadium; and area 4 in the eastern part has a moderate potential for resources of tungsten and molybdenum. The rest of the study area has a low resource potential for all metals. The entire study area has a low resource potential for nonmetals.

Four areas considered to have moderate mineral resource potential (fig. 1) were identified as geochemically anomalous by analysis of stream sediments and mesquite leaves. The anomalous characteristic elements and associated elements are listed in table 1.

Areas 1 and 2 have a moderate mineral resource potential for vein, greisen, pegmatite, and contactmetamorphic deposits in or related to Tertiary granite. Area 3 has possibilities for vein deposits of sulfide minerals in volcanic rocks. Area 4 has a moderate mineral resource potential for contact-metamorphic deposits in Precambrian rocks. The entire study area appears to be part of a much larger area that is anomalous in rare-earth elements (based on analyses for lanthanum and yttrium), zirconium, thorium, and tin, and that extends to the north and northwest.

There are no oil or gas leases or lease applications within the study area, although some have been made 


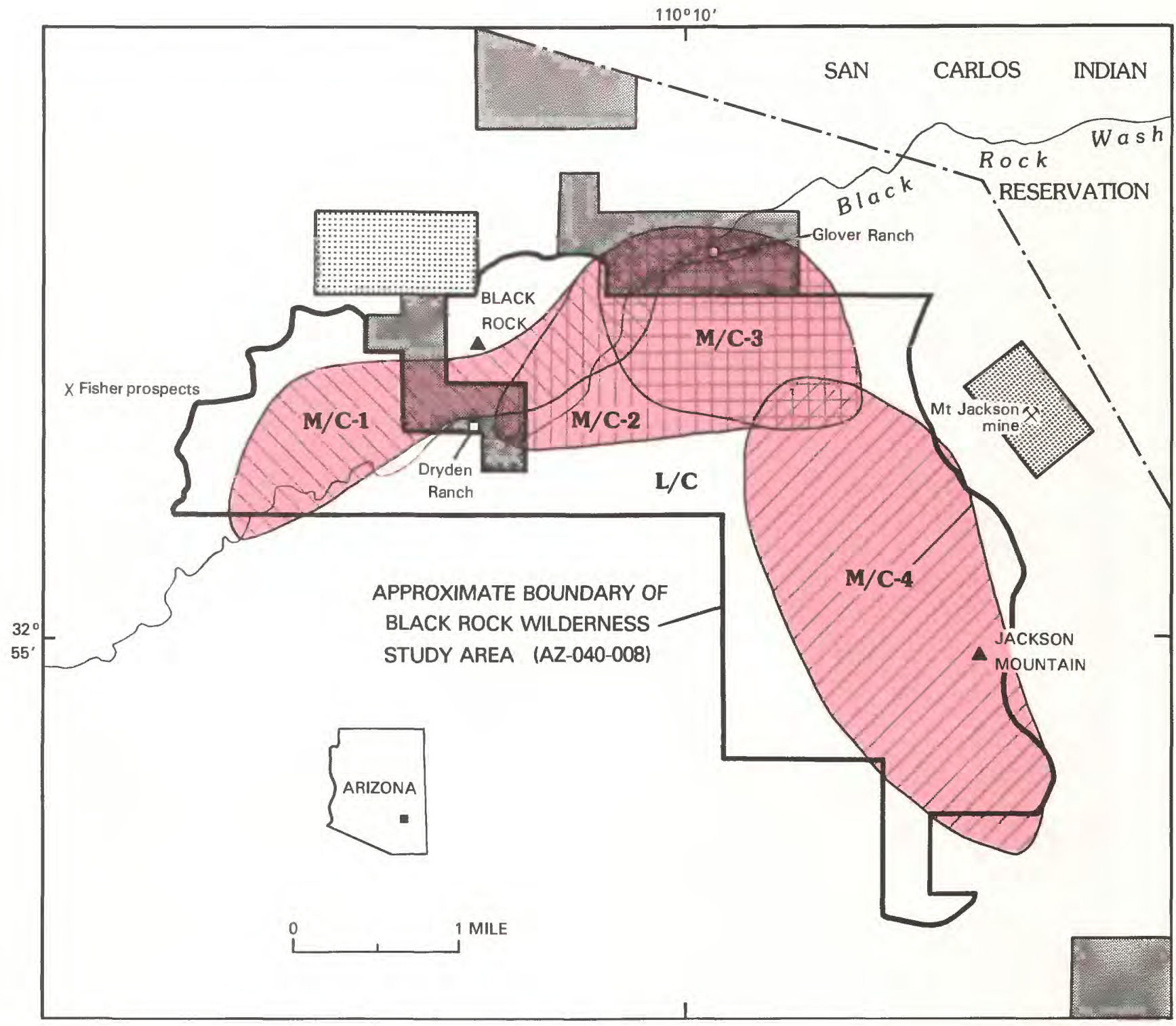

\section{EXPLANATION}

Geologic terrane having moderate mineral resource potential for metallic minerals

\begin{tabular}{|c|}
\hline$M / C-1$ \\
\hline$M / C-2$ \\
\hline$M / C-3$ \\
\hline$M / C-4$ \\
\hline
\end{tabular}

Rare-earth elements and thorium, and tin in western part

Thorium and beryllium

Copper, lead, molybdenum, cobalt, tin, and vanadium

Tungsten and molybdenum; southern part has low potential for copper and silver
L/C

Geologic terrane having low mineral resource potential for oil, gas, and geothermal energy

\section{Mining claim}

Oil and gas lease-As of April, 1983

Oil and gas lease application-As of April, 1983

Figure 1. Mineral resource potential map of the Black Rock Wilderness Study Area, Graham County, Arizona. 
in adjoining or nearby areas (fig. 1). No suitable source or reservoir rocks for oil and gas exist in the area, and the resource potential for such deposits is low. The resource potential for geothermal energy also is low.

\section{INTRODUCTION}

The Black Rock (AZ-040-008) Wilderness Study Area is in western Graham County, southeastern Arizona, about $27 \mathrm{mi}$ (miles) west-northwest of Safford and $48 \mathrm{mi}$ southeast of Globe (fig. 2). The study area covers 8,492 acres (about $10.32 \mathrm{mi}^{2}$ ) in the eastern foothills of the Santa Teresa Mountains. It is bounded to the southwest by the Coronado National Forest and elsewhere by private or other public land. The U.S. Geological Survey and the U.S. Bureau of Mines studied 6,590 acres of the Black Rock Wilderness Study Area. The study of this acreage was requested by the U.S. Bureau of Land Management. In this report, the area studied is called the "wilderness study area" or simply "study area."
Table 1. Anomalous elements in samples of stream sediments and mesquite leaves, Black Rock Wilderness Study Area, Arizona

\begin{tabular}{|c|c|c|}
\hline $\begin{array}{l}\text { Area } \\
\text { (fig. } 1, p l \cdot 1)\end{array}$ & $\begin{array}{c}\text { Characteristic } \\
\text { elements }\end{array}$ & $\begin{array}{l}\text { As sociated } \\
\text { elements }\end{array}$ \\
\hline $\begin{array}{l}1 \text { (entire area) } \\
\text { (western part) }\end{array}$ & $\begin{array}{l}\mathrm{La}, \mathrm{Th}, \mathrm{Y}- \\
\mathrm{Ba}, \mathrm{B}, \mathrm{Sn}\end{array}$ & $\begin{array}{l}\text { Sc, Co, Mn, Bi. } \\
\text { None. }\end{array}$ \\
\hline $2-\cdots$ & $\mathrm{Th}, \mathrm{Be}-\cdots$ & $\mathrm{Ba}, \mathrm{Sn}, \mathrm{Sc}, \mathrm{Bi}$. \\
\hline $3-\infty$ & $\begin{array}{l}\mathrm{Pb}, \mathrm{Mo}, \mathrm{V}, \mathrm{Cu}, \\
\text { Co, Sn. }\end{array}$ & $\begin{array}{l}\mathrm{Y}, \mathrm{Sc}, \mathrm{Th}, \mathrm{Ni}, \\
\mathrm{Zn}, \mathrm{Ag} .\end{array}$ \\
\hline $\begin{array}{l}4 \text { (entire area) } \\
\text { (southern part) }\end{array}$ & $\begin{array}{l}\mathrm{W}, \mathrm{Mo} \\
\mathrm{Cu}, \mathrm{Ag}\end{array}$ & $\begin{array}{l}\mathrm{Nb}, \mathrm{Ti} \\
\mathrm{Zn}, \mathrm{Ni}\end{array}$ \\
\hline
\end{tabular}

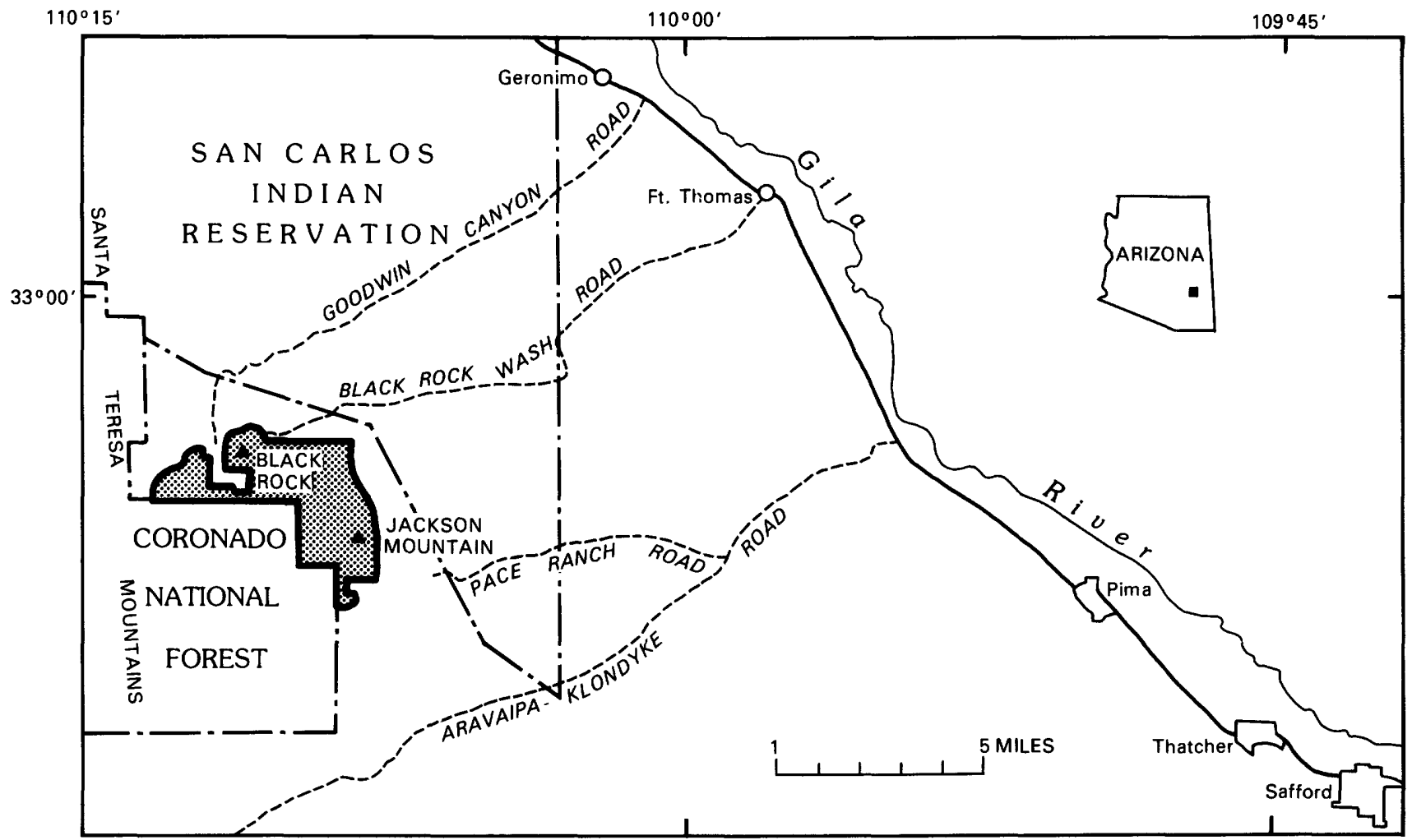

Figure 2. Index map showing the location of the Black Rock Wilderness Study Area, Graham County, Arizona. 
The main access to the study area is from Fort Thomas on U.S. Highway 70 , via an unpaved graded road up Black Rock Wash; this road ends at the Dryden (formerly Holladay) Ranch in the northwestern part of the study area (fig. 1). The southeastern part of the study area may be reached from the unpaved, graded AravaipaKlondyke road from U.S. Highway 70 via a branch road that ends at the Pace Ranch.

The study area ranges in altitude from about 3,600 $\mathrm{ft}$ along Black Rock Wash and its tributaries to 5,890 $\mathrm{ft}$ on Jackson Mountain in the southeastern part of the area. The predominant geographic feature is Black Rock, an oval intrusive body of rhyolite nearly $1 \mathrm{mi}$ long that rises $1,000 \mathrm{ft}$ above its surroundings and in its upper part is ringed by cliffs several hundred feet high.

\section{Investigations by the U.S. Bureau of Mines}

The U.S. Bureau of Mines investigation was done in 1983 by G. S. Ryan and included a review of U.S. Bureau of Land Management files for information on mining claims, an aerial reconnaissance, and collection of eight samples from prospects within the study area and five samples from nearby prospects.

\section{Investigations by the U.S. Geological Survey}

Geologic field work in the study area was done by F. S. Simons in 1983 and 1984. The Black Rock study area is entirely within the Jackson Mountain 1:62,500scale quadrangle (published in 1944), mapped geologically by Blacet and Miller (1978). Their work was used extensively in preparing the geologic map for this report. Thirty-six rock samples and $\mathbf{4 6}$ stream-sediment samples were collected in and near the study area. The geochemical study was done in 1983 by P. K. Theobald, R. R. Tidball, T. H. Harms, and J. A. Erdman. Thirty streamsediment samples, 30 heavy-mineral concentrates of stream sediments, and 29 samples of mesquite leaves were collected. Spectrographic and chemical analyses were done by T. H. Harms, L. A. Bradley, J. M. Motooka, and $\mathbf{N}$. M. Conklin. Interpretation of aeromagnetic and gravity geophysical data was by Andrew Griscom.

Acknowledgments.-We appreciate the cooperation of Volly and Chlo Dryden of the Dryden Ranch, and Art and Jane Glover of the Glover (formerly $T$ Hinton) Ranch in permitting access across their properties. Steve Knox of the Bureau of Land Management office in Safford provided historical data on the area.

\section{APPRAISAL OF IDENTIFIED RESOURCES}

\section{By George S. Ryan, U.S. Bureau of Mines}

\section{Mining and Mineral-Exploration Activity}

No mineral production has been recorded from the Black Rock Wilderness Study Area. Some mineral prospecting may have been done as early as 1880 , but most of the small exploration workings probably date from 1898-99 and were part of a fraudulent mining venture named Spenazuma (Ridgway, 1957). The small Mt. Jackson fluorspar mine $0.5 \mathrm{mi}$ east of the study area (fig. 1) is reported to have produced 1,200 tons of ore (Ryan, 1985). The Fisher copper prospects, in Fisher Canyon about $1 \mathrm{mi}$ west of the study area (fig. 1), have no recorded production (Ross, 1925, p. 103-105; Ryan, 1985). No exploration for oil or gas has been recorded by the Bureau of Land Mangement.

\section{Mines, Prospects, Claims, and Leases}

The study area has no identified reserves or resources (see resource/reserve classification chart on p. IV of this report). No mining claims are in the study area; the only claims nearby are the Mt. Jackson fluorspar claims, $0.5 \mathrm{mi}$ east of the study area. No oil or gas leases or lease applications have been recorded in the study area, but some are recorded on the northern and western borders of the area (fig. 1).

Exploration workings within the study area comprise several shallow shafts, small pits, and short adits, all in volcanic rocks. Some workings are on narrow fracture zones containing minor amounts of oxidized copper minerals, limonite, and quartz veinlets, but others show no structure or indication of alteration or mineralization. The largest fracture zone, at a prospect in Beauchamp Canyon 1.25 mi south of its confluence with Black Rock Wash, is $2-4 \mathrm{ft}$ wide as exposed in two prospect pits but could not be traced beyond the pits. None of these prospects suggests that mineral resources occur in the study area. Sample localities are shown on plate 1, and analytical data are summarized in table 2 . 
Table 2. Selected analytical data for samples collected by the U.S. Bureau of Mines from prospects in the Black Rock Wilderness Study Area, Arizona

[Copper, lead, and zinc analyzed by atomic-absorption spectrophotometry; gold and silver by fire assay; $\mathrm{Tr}$., trace; $\mathrm{N}$, not detected. Sample localities shown on pl. 1]

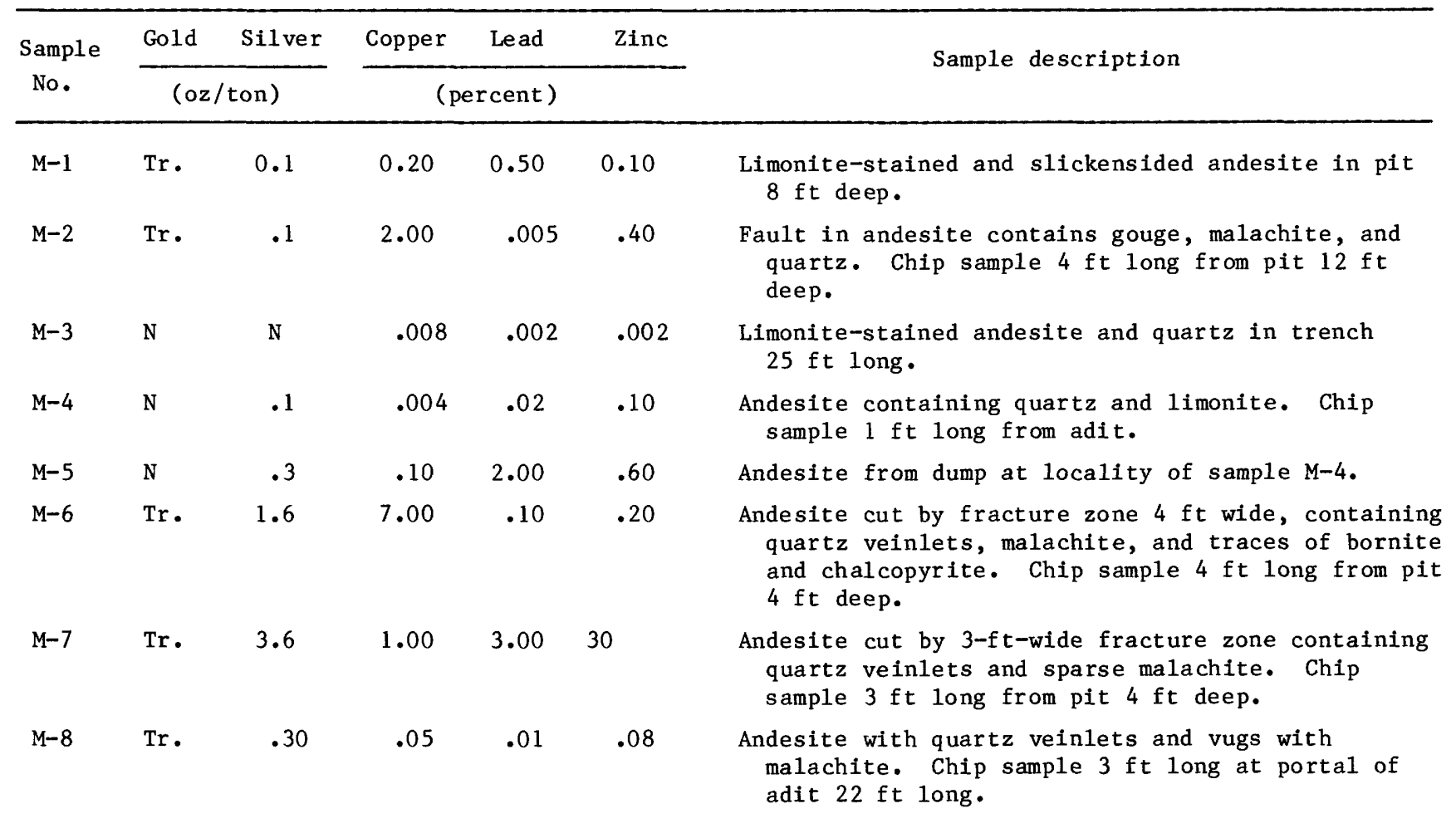

\section{ASSESSMENT OF POTENTIAL FOR UNDISCOVERED RESOURCES}

By Frank S. Simons, Paul K. Theobald, Ronald R. Tidball, James A. Erdman, Thelma F. Harms, and Andrew Griscom U.S. Geological Survey

\section{Geology}

The Black Rock Wilderness Study Area and adjoining areas are underlain mainly by four groups of rocks (pl. 1): metamorphic rocks of Proterozoic, mostly of Early Proterozoic age; Santa Teresa Granite of Tertiary age; volcanic rocks of various compositions, of Tertiary, perhaps of Oligocene or Miocene age; and fanglomerate and gravel of late Tertiary and Quaternary age. Contacts of Tertiary volcanic rocks with Proterozoic metamorphic and granitic rocks are along faults. Proterozoic rocks are intruded by Santa Teresa Granite, but the contact does not occur in the study area. All these units are overlain unconformably by fanglomerate and gravel.

The volcanic rocks, predominantly of rhyolitic or andesitic composition, underlie a northeast-trending wedge-shaped area of about $3 \mathrm{mi}^{2}$ that crosses the western side of the study area. To the west, volcanic rocks are in contact with Santa Teresa Granite along a north-trending fault that dips gently to moderately eastward. To the southeast, the volcanics are faulted against Proterozoic metamorphic rocks along a northeast-trending fault that dips gently to moderately northwestward. These faults converge to the southwest at the point of the volcanic wedge, but their juncture is concealed beneath the gravel cap that extends north from Mud Spring Mesa. They are interpreted to connect beneath the gravel and to constitute a single fault whose irregular surface slopes northeastward. If this interpretation is correct, then the volcanic 
Table 3. Selected analytical data for samples collected by the U.S. Geological Survey from prospects in and near the Black Rock Wilderness Study Area, Arizona

[Spectrographic analyses by D. E. Detra except as noted. Prospect G-6 showed no evidence of mineralization and was not sampled. Data in parts per million, percent in parentheses; N, not detected; L, detected but below lower limit of analytical determination; >, more than. Prospects numbered in a general way from northwest to southeast (pl. 1)]

\begin{tabular}{|c|c|c|c|c|c|}
\hline $\begin{array}{c}\text { Prospect } \\
\text { No. }\end{array}$ & Copper & Lead & Zinc & Silver & Molybdenum \\
\hline$G-1$ & $1_{40,000(4)}$ & 150 & $\mathrm{~N}$ & 1,000 & 10 \\
\hline$G-2$ & 200 & 150 & 300 & 1 & L \\
\hline$G-3$ & 100 & 150 & $\mathrm{~N}$ & 1 & 10 \\
\hline$G-4$ & $1_{33,000(3.3)}$ & 3,000 & $\mathrm{~N}$ & 1,000 & 10 \\
\hline$G-5$ & $>20,000(>2)$ & 100 & 1,000 & 20 & $\mathrm{~N}$ \\
\hline G-7 & $35,000(3.5)$ & $>20,000 \quad(>2)$ & ${ }^{2}>10,000(>1)$ & 200 & 300 \\
\hline
\end{tabular}

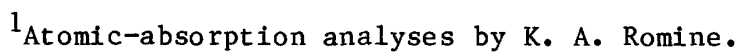

${ }^{2}$ Also contains $200 \mathrm{ppm}$ bismuth, $150 \mathrm{ppm}$ cadmium, and $500 \mathrm{ppm}$ tungsten. PROSPECT DESCRIPTIONS

G-1. Shaft $15 \mathrm{ft}$ deep to water. Fracture zone $3 \mathrm{ft}$ wide in gray and reddish-gray porphyritic andesite strikes N. $70^{\circ}$ W., dips $65^{\circ}$ S. Sparse films of malachite and chrysocolla, abundant epidote. Sample is of copper- and epidote-rich material from dump.

G-2. Shaft about $50 \mathrm{ft}$ deep on vertical north-striking fault in iron-stained, weak1y altered gray andesite. No evidence of mineralization. Chip sample across $5 \mathrm{ft}$ of andesite.

G-3. Shaft about $100 \mathrm{ft}$ deep in grayish-red-purple porphyritic andesite. No faults, joints, or evidence of mineralization. Chip sample of rock from nearby andesite outcrop.

G-4. Shaft $20 \mathrm{ft}$ deep on weak fracture zone in greenish-gray, fine-grained, porphyritic volcanic rock. Fracture strikes N. $15^{\circ}$ E., dips $80^{\circ}$ W. Sparse malachite. Sample is of copper-rich material from dump.

G-5. Shaft $40 \mathrm{ft}$ deep on weak fracture zone in coarsely porphyritic basalt. Zone is $10 \mathrm{ft}$ wide, strikes N. $20^{\circ}$ E., dips $80^{\circ}$ E. Traces of malachite and chrysocolla. Sample is of copper-rich material from dump.

G-6. Shaft filled with water nearly to surface, small dump. On brecciated and epidotized grayish-red andesite. No evidence of mineralization; not sampled.

G-7. One of a group of small prospects in andesitic volcanic rocks, west side of Beauchamp Canyon. Shaft 50-60 ft deep on vertical fracture zone that strikes northeast. Fractured rock has thin films of azurite, malachite, and iron oxide. Sample is of copper-rich material selected from a few tons of rock on dump. Highest prospect of group is a shallow shaft on a weak fracture zone in purple, fine-grained, glassy andesite. Fracture strikes northwest, dips $75-80^{\circ} \mathrm{NE}$. No visible evidence of mineralization.

rocks make up a rootless block floored by a fault whose surface is curved and generally trough shaped.

Data on prospects in or near the Black Rock study area that were examined during the geologic study are summarized in table 3. Two other mineral occurrences near the study area have been prospected and were examined briefly during this study. Copper prospects in Fisher Canyon about $1 \mathrm{mi}$ west of the study area (fig. 1, pl. 1) were described by Ross (1925, p. 103-105).
They consist of several adits, the longest estimated to be as much as $100 \mathrm{ft}$, and open pits on faults and fractures in Santa Teresa Granite. The prospects are scattered over an area $500 \mathrm{ft}$ long in a north-northwesterly direction. Individual fault zones are $0.5 \mathrm{ft}$ to several feet wide and contain chrysocolla and oxidized iron minerals.

A small amount of fluorspar was produced from the Mt. Jackson claims just east of the study area (fig. 1, pl. 1). The mineral deposit is a vein 4-10 ft wide and 
at least $700 \mathrm{ft}$ long along a fault in fine-grained Proterozoic granitic gneiss. The vein strikes $\mathrm{N}$. $40^{\circ} \mathrm{W}$. and dips $70-80^{\circ} \mathrm{NE}$, and consists of pale-green to colorless coarsegrained massive fluorite as much as $1 \mathrm{ft}$ wide, intergrown fluorite and quartz, sheared wall rock, and fine-grained diabase. The largest working is an opencut $160 \mathrm{ft}$ long at the southeastern end of the deposit; the opencut ends to the northwest in a partly caved stope of unknown depth.

Samples of apparently unmineralized rock were collected at 18 localities in order to determine the minor-element content of typical rocks of the study area. These samples included 11 of rhyolitic rocks from the vicinity of Black Rock, 1 of andesite from Black Rock Wash south of Black Rock, 2 of Santa Teresa Granite, and 4 of Proterozoic granitic gneiss. Localities of samples that contained anomalous amounts of one or more elements are shown on plate 1, and the anomalous elements and their amounts are shown in table 4. All but one of the rhyolites contained a trace of silver, but only one (sample 6) contained $0.5 \mathrm{ppm}$ or more.

\section{Geophysics}

Gravity data (Andrew Griscom and Craig Erdman, unpub. data, 1986, station spacing 0.5-3 mi) for the Black Rock Wilderness Study Area were reduced to isostatic residual gravity values in order to nearly eliminate isostatic effects of high topography and thus accentuate the effects of rock units of the upper crust with differing densities. The study area is on a gravity high ( +10 milligals) that forms part of a linear gravity high about $6 \mathrm{mi}$ wide and trending north for more than $30 \mathrm{mi}$. This linear gravity feature is over Proterozoic basement rocks that occur just to the east of a Tertiary granitic intrusion. The high gravity values imply somewhat higher density values for the Proterozoic rocks than for the adjacent younger rocks and probably reflect the various masses of mafic plutonic rocks that occur in the Proterozoic terrane.

Aeromagnetic data (Andrew Griscom and Craig Erdman, unpub. data, 1986, flight-line spacing $0.5 \mathrm{mi}$, nominal flight altitude $1,000 \mathrm{ft}$ above the ground) allow the differentiation between rock units having differing magnetic properties. Several small circular magnetic highs about $1 \mathrm{mi}$ in diameter are superimposed upon a larger magnetic high about $5 \mathrm{mi}$ across that is approximately centered on the study area. The individual magnetic highs may be associated with mafic plutonic rocks occurring within the Proterozoic terrane, but the source of the broader magnetic high is less clear. The Mount Jackson mine $0.5 \mathrm{mi}$ east of the study area, prospected mineralized areas in the study area in Beauchamp Canyon and Black Rock Wash, and prospects along the South Fork of Goodwin Canyon about 2 mi northwest of the study area appear to be associated with the flanks of the small magnetic
Table 4. Samples of other rocks, containing anomalous amounts of one or more minor elements, Black Rock Wilderness Study Area, Arizona

[Collected by the U.S. Geological Survey (pl. 1). Amounts, in parentheses, in parts per million; do, ditto]

\begin{tabular}{|c|c|c|}
\hline $\begin{array}{l}\text { Sample } \\
\text { No. }\end{array}$ & Rock type & $\begin{array}{l}\text { Anomalous element }(\mathrm{s}) \\
\text { and amounts }\end{array}$ \\
\hline 1 & Granite-- - & Silver (2); copper $(500)$ \\
\hline 2 & ----d o--------- & Silver $(0.5)$; copper $(100)$. \\
\hline 3 & Andesite------- & Silver $(0.5)$ \\
\hline 4 & Rhyolitem-- & Molybdenum (20). \\
\hline 5 & ----do-------- & Molybdenum (15). \\
\hline 6 & $----d o-\cdots------$ & $\begin{array}{l}\text { Silver (1.5); copper (200); } \\
\text { lead (500). }\end{array}$ \\
\hline 7 & Granitic gneiss & Silver (3); lead (100) \\
\hline 8 & $----d o------$ & Silver $(0.5)$; lead $(100)$ \\
\hline
\end{tabular}

anomalies, suggesting that there may be some relationship between magnetic highs and mineralization. The three mineralized areas also lie along the northern flank of the larger magnetic high. These empirical associations of magnetic features with mineralization are not understood at present because the sources of the magnetic anomalies are not clearly apparent.

\section{Geochemistry}

Three types of samples, stream sediments, heavymineral concentrates, and plants, were collected at each of 30 localities (pl. 1); at one locality no suitable plant material could be found. Stream-sediment samples were sieved to pass a 30 -mesh screen (approximately a 0.5 millimeter opening). These samples consisted of weathered material mechanically transported to the sample site. A concentrate of the heavy minerals contained in stream sediment was prepared by panning, separating the heavy fraction in bromoform (specific gravity 2.8 ), and removing iron and magnesium oxides and silicates by electromagnetic separation. The concentrate contains heavy and resistant minerals, some of which may be associated with ore deposits. Pulverized splits of the stream-sediment samples and heavy-mineral concentrates were analyzed for 31 elements by six-step optical emission semiquantitative spectrography (Grimes and Marranzino, 1968).

Samples of the leaves of honey mesquite (Prosopsis juliflora) were collected at 29 of the 30 sample localities. This plant provides information on soluble metals that are transported from the drainage basin and that are available 
at depth. Roots of mesquite are reported to extend to depths of as much as $165 \mathrm{ft}$ below the surface (Simpson, 1977). The mesquite samples were ashed, digested in nitric and hydrochloric acids, and 30 elements were determined in the solutions by inductively coupled plasma spectroscopy. Details of the sample collection, preparation, and analysis, together with the analytical data, were reported by Harms and others (1985).

Analytical data from the stream-sediment samples and heavy-mineral concentrates, and to a lesser extent from the mesquite samples, indicate that virtually the entire study area is characterized by anomalous amounts of thorium, zirconium, and rare earths. Within this broad geochemical anomaly, four more clearly defined anomalies were recognized (fig. 1, pl. 1); the southern part of area 4 contains another, less clearly defined anomaly (not separately outlined).

Area 1 (fig. 1, pl. 1) is characterized by the geochemical association lanthanum-thorium-yttrium, together with lesser scandium, cobalt, and manganese. Mesquite samples from the southeastern edge of this area were high in barium and boron, elements that are considered indicative of mineralization (Boyle, 1974, p. 15); the western part of the area is underlain by Santa Teresa Granite, whereas the eastern part is in volcanic rocks.

Area 2 is also marked by thorium as well as beryllium and lesser barium, tin, and scandium; the area is mainly in volcanic rocks. These element suites in areas 1 and 2 are characteristic of specialized granites and the mineral deposit types associated with them, such as pegmatites, greisens, and high-temperature veins.

Area 3 yielded samples high in vanadium, copper, cobalt, lead, tin, and molybdenum, together with minor scandium, thorium, and silver. Mesquite samples from this area were high in copper, zinc, magnesium, and nickel. The area is in the structurally complex northeastern part of the Tertiary volcanic terrane and coincides with the eastern two-thirds of area 2 . It is considered to reflect the occurrence of metal sulfides in the source areas.

Area 4 is characterized by samples that were relatively high in tungsten, molybdenum, and calcium, with lesser amounts of niobium and titanium. The area is underlain entirely by Proterozoic granitic gneiss, and the anomaly reflects the occurrence of scheelite (calcium tungstate) and powellite (calcium molybdate) in the source terrane. In the southern part of area 4, samples high in copper and silver were from drainages in which Proterozo- ic diabase dikes intrude the gneiss. Mesquite samples from this part of area 4 yielded data similar to those from samples in area 3.

\section{Mineral and Energy Resources}

The assemblage of rare-earth elements, thorium, and tin in area 1 , and the assemblage of thorium and beryllium in area 2 (fig. 1, pl. 1) are characteristic of samples derived from specialized granites, which commonly are hosts of or are associated with vein, greisen, pegmatite, or contact-metamorphic mineral deposits. Such deposits might occur in or be related to the Santa Teresa Granite and would have formed during a Tertiary period of mineralization. Areas 1 and 2 have a moderate mineral resource potential for these types of deposits, with certainty level C (Goudarzi, 1984; see inside front cover of this report).

The assemblage of base metals (lead, copper) plus molybdenum, cobalt, tin, and vanadium (area 3 ) is typical of samples derived from geologic terranes that contain sulfide deposits of these elements. In the study area, small vein deposits of this type occur at several prospects in volcanic rocks. Area 3 has a moderate resource potential for such deposits, with certainty level C.

The assemblage tungsten-molybdenum, with lesser niobium and titanium (area 4) occurs in samples that contain contact-metasomatic minerals of the scheelite-powellite series (calcium tungstate-calcium molybdate). Deposits of these minerals could occur in Proterozoic gneiss or other metamorphic rocks in the study area, but no deposits were recognized during this study. These mineral occurrences are probably unrelated to those indicated by the other anomalies. Area 4 has a moderate mineral resource potential for scheelite-powellite deposits, with certainty level $\mathrm{C}$. The copper-silver geochemical anomaly in the southern part of area 4 appears to be related to the structural elements controlling emplacement of Proterozoic diabase dikes that intrude granitic gneiss, but few data are available, and the relationship of this anomaly to the others is unknown. Therefore, the mineral resource potential for copper and silver is low, with certainty level B.

No source or reservoir rocks suitable for the accumulation of oil, gas, or geothermal energy are known in the study area, and the energy resource potential for the area is low, with certainty level $\mathrm{C}$. 


\section{REFERENCES CITED}

Blacet, P. M., and Miller, S. T., 1978, Reconnaissance geologic map of the Jackson Mountain quadrangle, Graham County, Arizona: U.S. Geological Survey Miscellaneous Field Studies Map MF-939, scale 1:62,500.

Boyle, R. W., 1974, Elemental associations in mineral deposits and indicator elements of interest in geochemical prospecting: Geological Survey of Canada Paper 74-45, 40 p.

Goudarzi, G. H., compiler, 1984, Guide to preparation of mineral survey reports on public lands: U.S. Geological Survey Open-File Report 84-787, 42 p.

Grimes, D. J., and Marranzino, A. P., 1968, Direct-current arc and alternating-current spark emission spectrographic field methods for the semiquantitative analysis of geologic materials: U.S. Geological Survey Circular 591, 6 p.

Harms, T. F., Bradley, L. A., Tidball, R. R., Motooka, J.
M., and Conklin, N. M., 1985, Analytical results and sample locality maps of stream sediments, heavy-mineral concentrates, and plant samples from Black Rock, Fishhooks, and Needles Eye Wilderness Study Areas, Graham and Gila Counties, Arizona: U.S. Geological Survey Open-File Report $85-462,49$ p., 3 plates.

Ridgway, W. R., 1957, Spenazuma: Arizona Highways, January, 1957, p. 30-35.

Ross, C. P., 1925, Geology and ore deposits of the Aravaipa and Stanley mining districts, Graham County, Arizona: U.S. Geological Survey Bulletin 763, 120 p.

Ryan, G. S., 1985, Mineral investigation of the Black Rock Wilderness Study Area, Graham County, Arizona: U.S. Bureau of Mines Open File Report MLA 5-85, 13 p.

Simpson, B. B., ed., 1977, Mesquite-its biology in two desert ecosystems: Stroudsburg, Pa.; Dowden, Hutchinson and Ross, Inc., 250 p. 
GEOLOGIC TIME CHART

Terms and boundary ages used by the U.S. Geological Survey, 1986

\begin{tabular}{|c|c|c|c|c|c|}
\hline EON & ERA & \multicolumn{2}{|c|}{ PERIOD } & $\mathrm{EPOCH}$ & $\begin{array}{l}\text { BOUNDARY AGE } \\
\text { IN } \\
\text { MILLION YEARS }\end{array}$ \\
\hline \multirow{17}{*}{ Phanerozoic } & \multirow{7}{*}{ Cenozoic } & \multirow{2}{*}{\multicolumn{2}{|c|}{ Quaternary }} & Holocene & L 010 \\
\hline & & & & Pleistocene & {$[0.070$} \\
\hline & & \multirow{5}{*}{ Tertiary } & \multirow{2}{*}{$\begin{array}{l}\text { Neogene } \\
\text { Subperiod }\end{array}$} & Pliocene & 5 \\
\hline & & & & Miocene & \\
\hline & & & \multirow{3}{*}{$\begin{array}{l}\text { Paleogene } \\
\text { Subperiod }\end{array}$} & Oligocene & 24 \\
\hline & & & & Eocene & \\
\hline & & & & Paleocene & \\
\hline & \multirow{3}{*}{ Mesozoic } & \multicolumn{2}{|c|}{ Cretaceous } & $\begin{array}{l}\text { Late } \\
\text { Early }\end{array}$ & -96 \\
\hline & & \multicolumn{2}{|c|}{ Jurassic } & $\begin{array}{l}\text { Late } \\
\text { Middle } \\
\text { Eariy }\end{array}$ & -138 \\
\hline & & \multicolumn{2}{|c|}{ Triassic } & $\begin{array}{c}\text { Late } \\
\text { Middle } \\
\text { Early }\end{array}$ & 205 \\
\hline & \multirow{7}{*}{ Paleozoic } & \multicolumn{2}{|c|}{ Permian } & $\begin{array}{l}\text { Late } \\
\text { Early }\end{array}$ & $\sim 240$ \\
\hline & & \multirow{2}{*}{$\begin{array}{c}\text { Carboniferous } \\
\text { Periods }\end{array}$} & Pennsylvanian & $\begin{array}{l}\text { Late } \\
\text { Middle } \\
\text { Early }\end{array}$ & 25 \\
\hline & & & Mississippian & $\begin{array}{l}\text { Late } \\
\text { Early }\end{array}$ & \\
\hline & & \multicolumn{2}{|c|}{ Devonian } & $\begin{array}{l}\text { Late } \\
\text { Middle } \\
\text { Early }\end{array}$ & 500 \\
\hline & & \multicolumn{2}{|c|}{ Silurian } & $\begin{array}{l}\text { Late } \\
\text { Middle } \\
\text { Early }\end{array}$ & 410 \\
\hline & & \multicolumn{2}{|c|}{ Ordovician } & $\begin{array}{l}\text { Late } \\
\text { Middle } \\
\text { Early }\end{array}$ & 435 \\
\hline & & \multicolumn{2}{|c|}{ Cambrian } & $\begin{array}{l}\text { Late } \\
\text { Middle } \\
\text { Early }\end{array}$ & 500 \\
\hline \multirow{3}{*}{ Proterozoic } & Late Proterozoic & & & & \\
\hline & Middle Proterozoic & & & & \\
\hline & Early Proterozoic & & & & \\
\hline \multirow{3}{*}{ Archean } & Late Archean & & & & 2500 \\
\hline & Middle Archean & & & & \multirow{2}{*}{$\begin{array}{l}-3000 \\
-3400\end{array}$} \\
\hline & Early Archean & & & & \\
\hline
\end{tabular}

'Rocks older than $570 \mathrm{~m}$.y. also called Precambrian, a time term without specific rank.

${ }^{2}$ Informal time term without specific rank. 